\title{
Systematic Review \\ The Role of Biomimetic Hypoxia on Cancer Cell Behaviour in 3D Models: A Systematic Review
}

\author{
Ye Liu ${ }^{1, *}$, Zahra Mohri ${ }^{2}$, Wissal Alsheikh ${ }^{1}$ and Umber Cheema ${ }^{1, *}$ \\ 1 UCL Centre for 3D models of Health and Disease, Division of Surgery and Interventional Sciences University \\ College London, London WC1E 6BT, UK; wissal.alsheikh.19@ucl.ac.uk \\ 2 Medical Biosciences, Faculty of Medicine, Imperial College London, London SW7 2BU, UK; \\ z.mohri@imperial.ac.uk \\ * Correspondence: aliceliu@doctors.org.uk (Y.L.); u.cheema@ucl.ac.uk (U.C.)
}

check for updates

Citation: Liu, Y.; Mohri, Z.; Alsheikh, W.; Cheema, U. The Role of Biomimetic Hypoxia on Cancer Cell Behaviour in 3D Models: A Systematic Review. Cancers 2021, 13, 1334. https://doi.org/10.3390/ cancers13061334

Academic Editors: Ciro Isidoro,

Danny N. Dhanasekaran and Sudip K. Das

Received: 27 January 2021

Accepted: 13 March 2021

Published: 16 March 2021

Publisher's Note: MDPI stays neutral with regard to jurisdictional claims in published maps and institutional affiliations.

Copyright: (C) 2021 by the authors. Licensee MDPI, Basel, Switzerland. This article is an open access article distributed under the terms and conditions of the Creative Commons Attribution (CC BY) license (https:// creativecommons.org/licenses/by/ $4.0 /)$.
Simple Summary: Cancer remains one of the leading causes of death worldwide. The advancements in 3D tumour models provide in vitro test-beds to study cancer growth, metastasis and response to therapy. We conducted this systematic review on existing experimental studies in order to identify and summarize key biomimetic tumour microenvironmental features which affect aspects of cancer biology. The review noted the significance of in vitro hypoxia and 3D tumour models on epithelial to mesenchymal transition, drug resistance, invasion and migration of cancer cells. We highlight the importance of various experimental parameters used in these studies and their subsequent effects on cancer cell behaviour.

Abstract: The development of biomimetic, human tissue models is recognized as being an important step for transitioning in vitro research findings to the native in vivo response. Oftentimes, 2D models lack the necessary complexity to truly recapitulate cellular responses. The introduction of physiological features into 3D models informs us of how each component feature alters specific cellular response. We conducted a systematic review of research papers where the focus was the introduction of key biomimetic features into in vitro models of cancer, including 3D culture and hypoxia. We analysed outcomes from these and compiled our findings into distinct groupings to ascertain which biomimetic parameters correlated with specific responses. We found a number of biomimetic features which primed cancer cells to respond in a manner which matched in vivo response.

Keywords: 3D; cancer models; hypoxia; cancer stem cells; drug resistance; epithelial-to-mesenchymal transition; invasion; migration

\section{Introduction}

Cancer remains one of the leading causes of death despite notable advances in modern medicine [1]. In vitro research has been key to understanding in vivo tumour cellular growth and progression. Since the initial discovery of 2D cell culture techniques in 1907 [2,3], many have used these techniques to study the tumour microenvironment but advances in 3D cell culture and bioengineering techniques have gone further in truly recapitulating in vivo tumour cellular characteristics such as pericellular hypoxia, epithelial-tomesenchymal transition (EMT) and response to various chemotherapy agents.

Several previous literature reviews of experimental studies involving 2D and 3D in vitro tumour models, the microenvironmental features of different tumour models and drug responses have drawn conclusions that 3D in vitro tumour models mimic physiological characteristics and display biomimetic response to chemotherapy [3-12]. However what lacks in existing literature is an updated comprehensive systematic analysis of how specific micro-environmental features direct or alter such cellular response.

In this review we have systematically analysed the effect of the addition of biomimetic features, including physiological hypoxia and 3D culture, on cancer cell behaviour. We 
have focused in particular on cancer cell growth, invasion, EMT and response to therapeutic interventions within biomimetic 3D cultures.

\section{Materials and Methods}

The systematic review was conducted using a number of search engines including "Medline", "Embase" and "Web of Science" with the same initial search terms: "cancer" and "hypoxia", then narrowed down further using terms including " $2 \mathrm{D}$ " and " $3 \mathrm{D}$ " for all databases used. The databases above were all accessed on 28 May 2020. All publications in English language until 28 May 2020 were included for screening. Spelling variations and similar search terms were included for thorough inclusion of existing publications (Table 1).

Table 1. Search terms.

\begin{tabular}{cc}
\hline Search Terms & Synonym/Alternative Spellings \\
\hline Hypoxia & - \\
\hline Cancer & Neoplasm/tumor/tumour \\
\hline 2D & 2 dimension/two dimension \\
\hline 3D & 3 dimension/three dimension \\
\hline
\end{tabular}

Inclusion and exclusion criteria were decided and a total of 475 citations were identified through the initial search, excluding duplications, non-full text and non-eligible publications according to the exclusion criteria, 141 publications were deemed eligible for systematic qualitative analysis (Table 2, Figure 1).

Table 2. Inclusion and exclusion criteria.

\begin{tabular}{cc}
\hline Inclusion Criteria & Exclusion Criteria \\
\hline All cancer types & Review articles \\
\hline In vitro and in vivo studies & Computer simulations \\
\hline 2D and 3D studies & Non cancer \\
\hline Hypoxia studies & Non full text publications \\
\hline
\end{tabular}

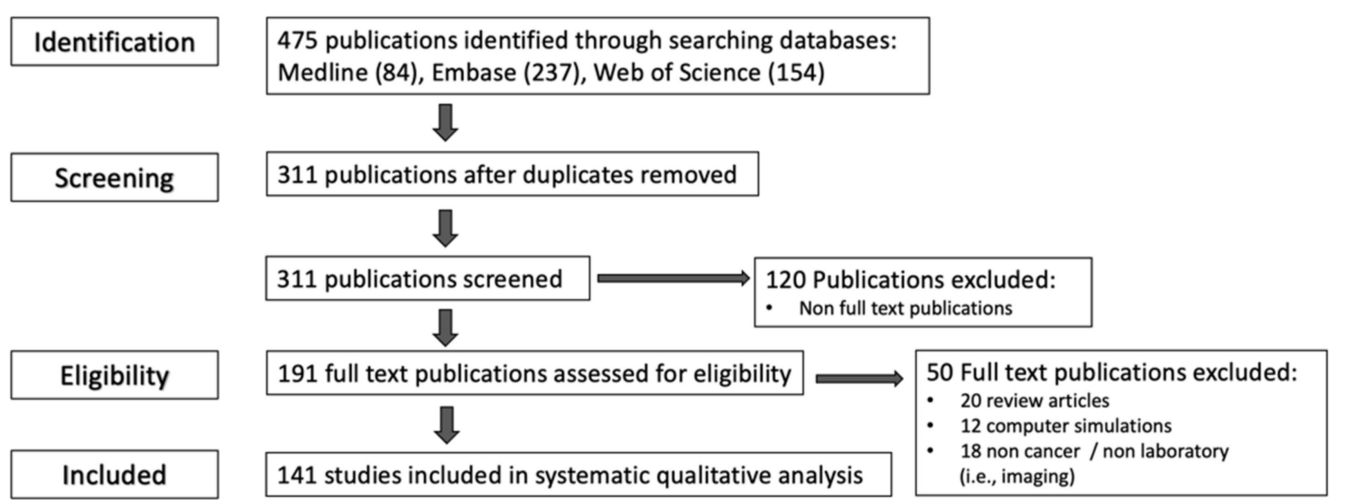

Figure 1. Number of publications excluded at each phase of the publication selection process and reasons for exclusion.

Lists of materials, methods, outcomes and conclusions from each publication were recorded via an Excel spreadsheet. To minimize outcome reporting bias, data collection was conducted by two independent investigators, with a third investigator comparing the two data sets for discrepancies and any identified were further analysed by a fourth investigator before final outcome from the specific publication was recorded for the qualitative analysis. 


\section{Results}

\subsection{Level of Hypoxia and Duration}

Pathological hypoxia plays an established role in tumour growth, invasion and migration, involving mechanisms such as EMT, angiogenesis and glucose metabolism. Tumour masses of over 500 micrometer diameters display gradients of oxygen concentration, affecting aspects of tumour growth as described above [5]. Therefore, it would come as no surprise that $3 \mathrm{D}$ in vitro tumour models will display a degree of intrinsic hypoxia regardless of external hypoxia represented as $\mathrm{pO}_{2}$ or partial pressure of oxygen in the overlaying media. The $\mathrm{pO}_{2}$ within $3 \mathrm{D}$ cultures can drop to $0 \%$ causing cell migration away from the core of 3D cultures where this is measured directly within 3D tissue models [13].

In this review a total of 51 publications [14-64] utilized various levels of external hypoxia control, primarily through control of the atmospheric oxygen level of the chamber. The remaining studies validated hypoxia through a number of different routes including; internally generated hypoxia within cultures through the use of $\mathrm{pO}_{2}$ probes to measure the media and or 3D tumour models for dissolved oxygen; stains such as pimonidazole [23] as a tumour hypoxia marker and the upregulation of Hypoxia-Inducible Factor as an indicator of hypoxia. Publications involving multiple studies with different hypoxia levels, yielded a total of 65 studies. Levels of external hypoxia within these studies ranged from $0.1 \%$ to $10 \%$ oxygen, with $71 \%$ of studies using a hypoxic level of $1 \%$ oxygen or less. Control cultures for normoxia were set at either $20 \%$ or $21 \%$ oxygen with the exception of one study that used $17 \%$ oxygen [17]. The hypoxic exposure time for these studies range between $2 \mathrm{~h}$ and 70 days with $71 \%$ of studies exposing cultures to hypoxic condition for $72 \mathrm{~h}$ or less, and $52 \%$ of studies using specifically 24 or $48 \mathrm{~h}$.

When directly measuring oxygen in tissues, this is done so by measuring the partial pressure of oxygen $(\mathrm{mmHg})$ and therefore reported levels of tissue oxygenation use this measure. The $\mathrm{pO}_{2}$ of arterial blood is a measure of the effectiveness of transfer of oxygen from the atmosphere (air) by the lungs. Once dissolved, this oxygen is measured using $\mathrm{mmHg}$ units, and $7.8 \mathrm{mmHg}$ is roughly equivalent to $1 \%$ atmospheric oxygen. The majority of studies in this review have not directly measured hypoxia in 3D cultures, but instead utilised hypoxia chambers to control or "set" the free atmospheric oxygen. Many researchers will rely upon the equilibrium achieved between free atmospheric oxygen of the chamber and dissolved oxygen in the culture media, and thus this was difficult to verify for each study. There are issues around how quickly this process occurs, especially given aspects such as: (i) the constant temperature of the culture; (ii) the opening and closure of hypoxia chambers, which can cause fluctuations in oxygen tension; (iii) an understanding of the oxygen diffusion coefficient of the 3D scaffold materials used in 3D culture and; (iv) the multiple monitoring of the media $\mathrm{pO}_{2}$ and the $3 \mathrm{D}$ culture $\mathrm{pO}_{2}$, which should preferably be done in the core and at the surface [65].

Tissue normoxia, measured as $\mathrm{pO}_{2}$, is distinct from atmospheric oxygen concentration, which is $21 \%$ in air [66]. Existing literature has shown that normal human tissue-specific oxygen concentration lies between 2 and $6 \%$ oxygen, termed physiological hypoxia, with average normal tissue oxygenation not far above that of 3 to $7.4 \%$ oxygen [67]. Taking into account the average range of oxygen concentrations within an untreated tumour which is described in existing literature to range between 0.3 to $4.2 \%$ oxygen [67], one would expect studies involving in vitro tumour models to incorporate the above factors, but surprisingly nearly a third of the studies still used oxygen levels of $2 \%$ or above, which coincides with the average range for normal physiological hypoxia. Furthermore, the half maximum expression of HIF1a and HIF1b was found to be between 1.5 to $2 \%$ oxygen, with the maximum expression at $0.5 \%$ or less oxygen. Considering the substantial regulatory effects of HIFs on tumour growth and invasion, especially its proangiogenic properties, careful selection of oxygen concentrations in hypoxia studies should be pertinent and taken into account in experimental designs for in vitro tumour cultures to truly recapitulate the in vivo microenvironment (Figure 2). 


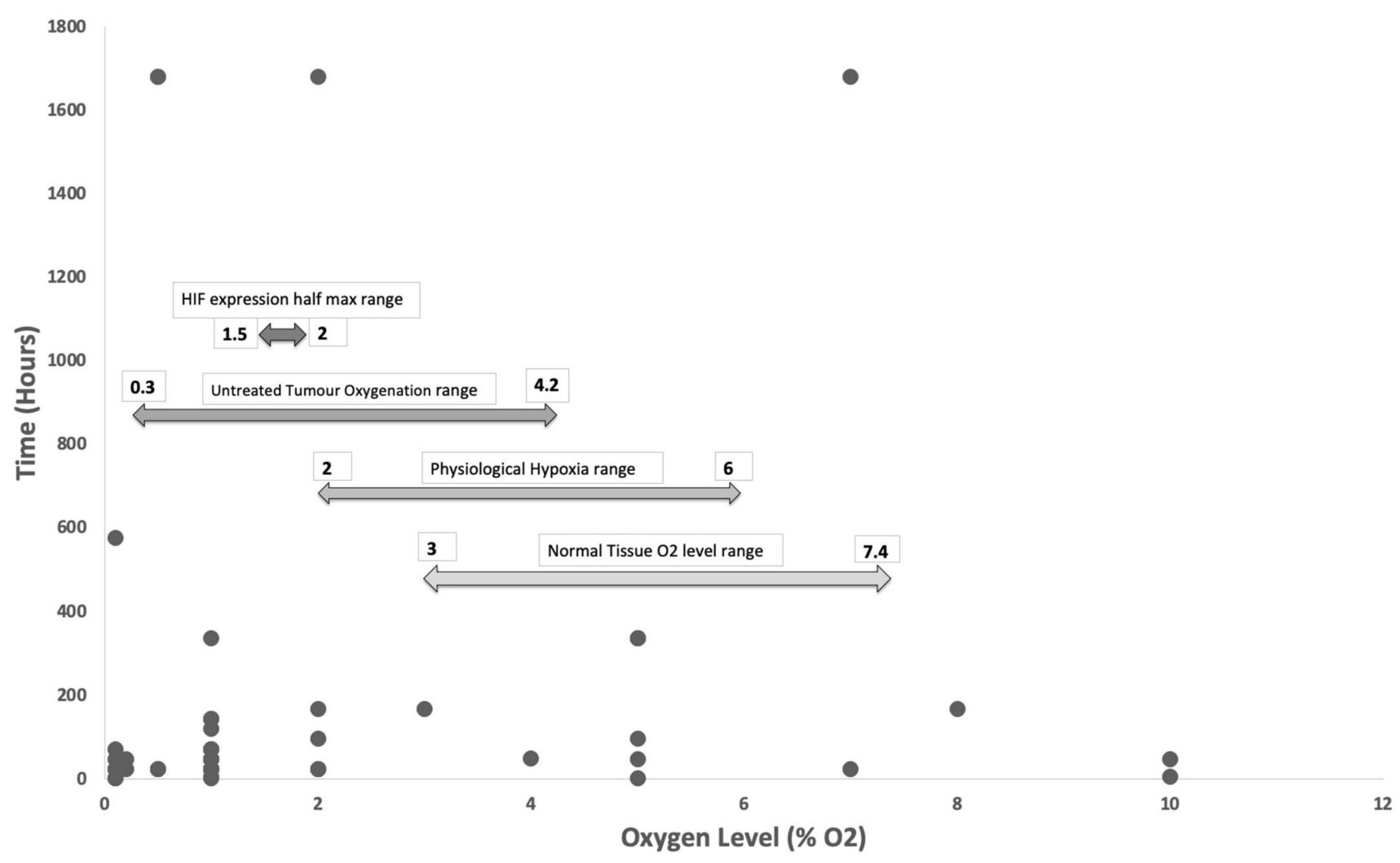

Figure 2. Hypoxia level vs Duration. 71\% of studies explored oxygen levels of $1 \%$ or below and $71 \%$ of studies exposed in vitro cultures for $72 \mathrm{~h}$ or less. Arrows demonstrating oxygen range of normal tissue, physiological hypoxia, untreated tumours pathological hypoxia and HIF half maximum expression range. Several studies used oxygen levels outside of the range of physiological tissue hypoxia.

\subsection{Scaffold and Non-Scaffold Based Approaches Are Used Equally in 3D Cancer Studies}

$3 \mathrm{D}$ tumour models are considered to better recapitulate the in vivo tumour microenvironment compared to standard 2D cultures. In this review we have identified a total of 37 publications $[34,50,57,60,62,64,68-98]$ where $3 \mathrm{D}$ culture significantly altered cancer cell behaviour towards a more biomimetic response. Eighteen of these studies used 3D scaffoldbased cultures and 18 studies used non scaffold-based, cell-generated extra-cellular matrix (ECM) cultures, with a single study using both approaches [73] (Figure 3). Looking further into the scaffold-based cultures, we found that $54 \%$ of studies used non-native scaffold materials and $46 \%$ using native scaffold materials. Of each of the cohorts above alginate gel was the most used non-native scaffold and collagen for native scaffold material (Figure 4).

These studies used a variety of measurements to determine the extent of biomimicry within in vitro cultures, using a range of criteria including: Genetic expression of angiogenic and matrix remodelling genes, protein synthesis of angiogenic, invasive and matrix remodelling molecules,; morphological basis involving regulators such as expression of hypoxia induced factors, proangiogenic factors, EMT markers, and factors associated with tumour cell stemness; increased IL-8 expression; measured increases in growth of cancer and invasion. 


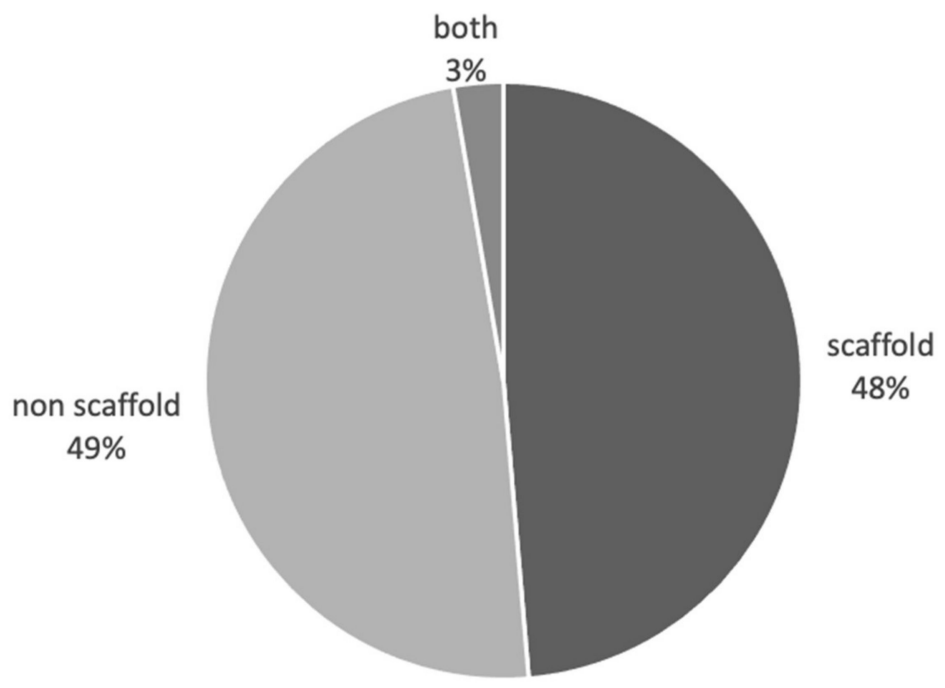

Figure 3. Biomimicry studies: scaffold vs non scaffold vs both. Proportional representation of number of studies using scaffold, non-scaffold-based tumour cultures in biomimicry studies.

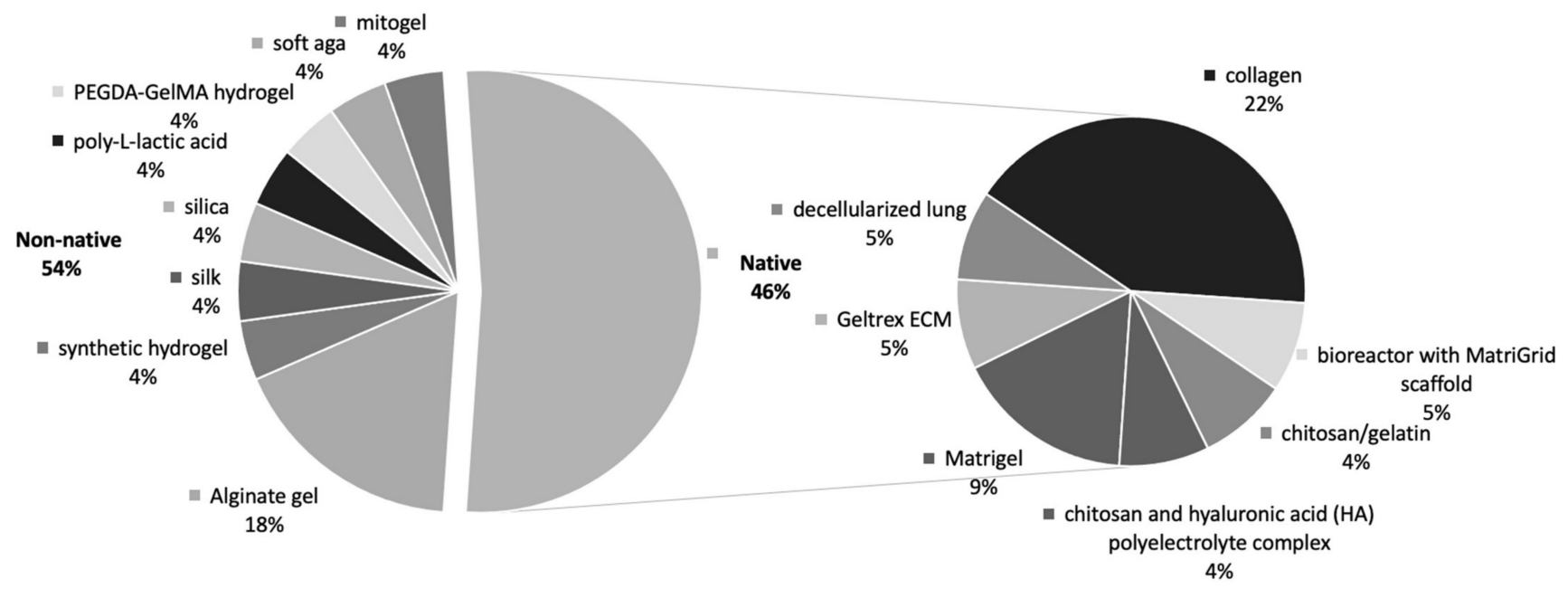

Figure 4. Scaffold Types in biomimicry studies. Type of scaffolds used in scaffold-based studies regarding biomimicry of in vitro cancer cultures. Similar proportion seen of native vs non-native materials for scaffold cultures.

\subsection{D and Hypoxia Enrich Cancer Stem Cell Expression}

3D culture and the presence of hypoxia, measured by the various methods outlined in Section 3.2, enhances cancer stem cell (CSC) expression when compared to 2D or normoxic cultures. A total of 14 publications were identified that described measurable changes in various CSC between 2D and 3D in vitro tumour models [19,21,23,48,72-74,89,92,99-103]. 13 out of the 14 publications showed increased CSC markers in 3D than 2D cultures and one publication [99] stated the latter. Of the 13 publications describing 3D cultures displaying upregulated CSC markers, the tumour models used were mainly scaffold-based (64\%) compared to non-scaffold-based (36\%). Furthermore, $67 \%$ of those scaffold-based cultures comprised of native scaffold materials rather than non-native materials (33\%). Measurable markers of CSC expression vary between each publication, but we identified the most frequently used markers include CD44 [48,72,74,89,100,101,103], OCT4 [19,23,73,99,102], NANOG [23,72,99], SOX2 [21,100], CD133 [48,72,74] and ALDH1A [23,48,74,103]. We noted in one publication the expression of HIF-1 and SOX2 via immunofluorescent staining displayed more pronounced expressions towards the peripheries of the 3D spheroids. The 
upregulation of these markers were also analysed through RNA sequence analysis and western blots [21].

\subsection{D Models Enhances Measurable EMT in Cancer Cultures, with Scaffold-Based Cultures Playing a Key Role}

EMT is a process identified as one of the key features in tumour invasion and metastasis. We identified a total of 19 publications $[15,24,50,69,73,74,76,82,84,92,94,99-102,104-107]$ comparing markers of EMT in 2D vs. 3D tumour cultures, with 18 of those showing enhanced measurements of EMT in 3D compared to 2D cultures. In contrast with the generalised cohort of studies concerning biomimicry of in vitro cancer cultures, the studies specifically concerning EMT consisted of a majority of scaffold-based cultures at $67 \%$, and $33 \%$ involving non-scaffold-based cultures. This emphasises that we have identified a positive correlation on the presence of high levels of ECM in cancer cultures to the process of EMT (Figure 5).

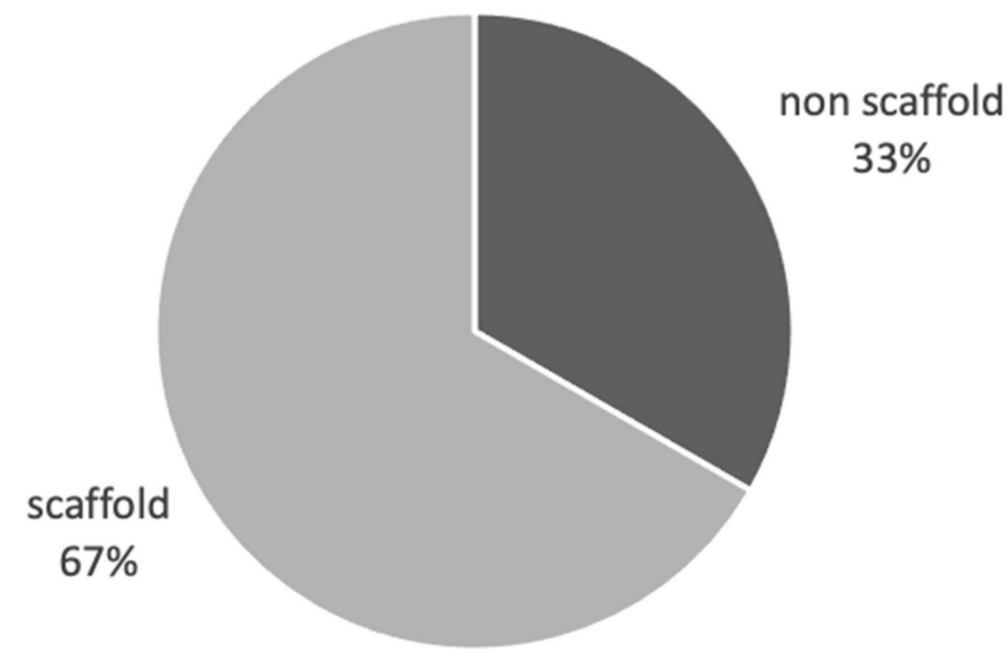

Figure 5. EMT studies: Scaffold vs. non scaffold. Proportional representation of scaffold and non-scaffold based studies exploring EMT, highlighting the importance of ECM in the process.

\subsection{Culturing Cancer Cells in 3D Enhances Drug Resistance}

We identified a total of 42 publications $[16,19,22,23,30,41,42,45,49,52,56,59,61,64,68,72$, $74,80,85,89,100-103,105,106,108-123]$ comparing cell response to chemotherapy and other interventions between 2D and 3D in vitro tumour models, using a variety of anticancer agents and taking into account any publications which involved more than one type of anticancer agents, yielding in total 85 separate findings, including 79 outcomes concerning chemotherapy agents, three involving radiotherapy, and a further five exploring natural compound agents such as orange-peel flavones. The definitions for drug response varied throughout the studies in terms of markers used and duration over which drug responses were measured. The definition of drug response was variable and included measurements of tumour or spheroid size, viability at 3 days, proliferation rates, expression of angiogenetic and metastatic markers pre- and post-drug exposure.

Overall, $85 \%$ of experimental outcomes showed 3D tumour cultures displayed increased resistance to anticancer therapies and 15\% showed increased sensitivity in 3D when compared with $2 \mathrm{D}$ cultures. Of those which showed increased sensitivity in $3 \mathrm{D}$, the therapies tested were predominantly proapoptotic agents, novel targeted therapy, hypoxia activated drugs, radiotherapy or natural compounds (Figure 6). 


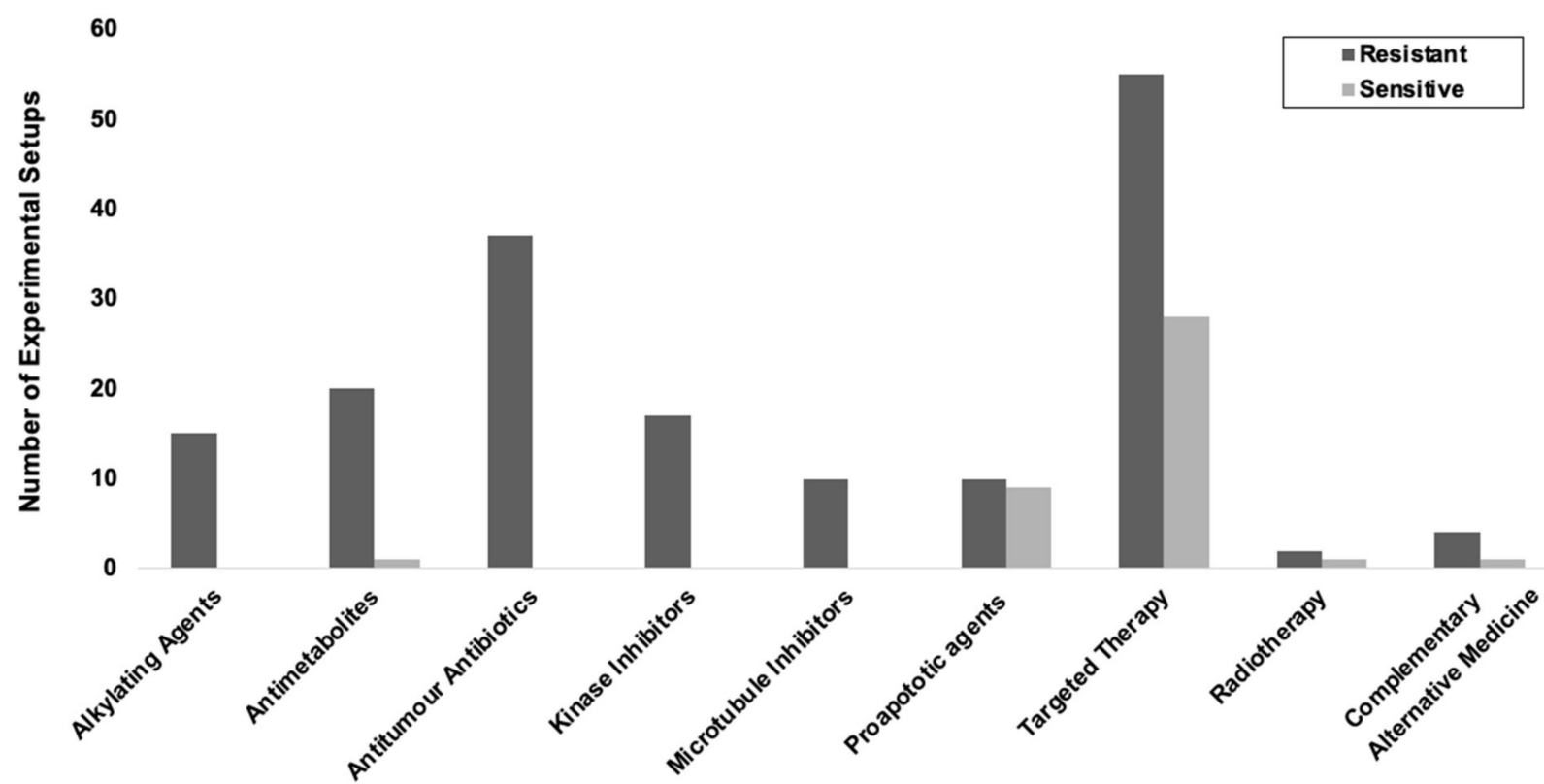

Figure 6. Cancer cell resistance or sensitivity to chemotherapy agents. Response to all therapy classes conveyed a trend of increased resistance to therapy in $3 \mathrm{D}$ in vitro tumour cultures compared to $2 \mathrm{D}$ cultures. Furthermore, five out of six of the conventional chemotherapy classes expressed congruent response of increased resistance to therapy in all experimental setups in 3D compared to 2D.

Furthermore, we investigated the specific response from each cancer type to multiple therapeutic interventions. We categorized the cell lines into 11 organ systems. All cancer types showed a trend of overall increased resistance in 3D compared to 2D in vitro tumour cultures. Most cancer types showed similar responses ranging from $72 \%$ to $88 \%$ of studies displaying enhanced resistance to chemotherapy in 3D. Studies involving urological and head \& neck cancers reported 100\% chemo resistant outcome in 3D, whereas prostate cancers and sarcomas showed a significantly lower proportion for chemo resistant outcomes in $3 \mathrm{D}$ compared to other cancer types at $57 \%$ and $56 \%$ prospectively (Figure 7 ).
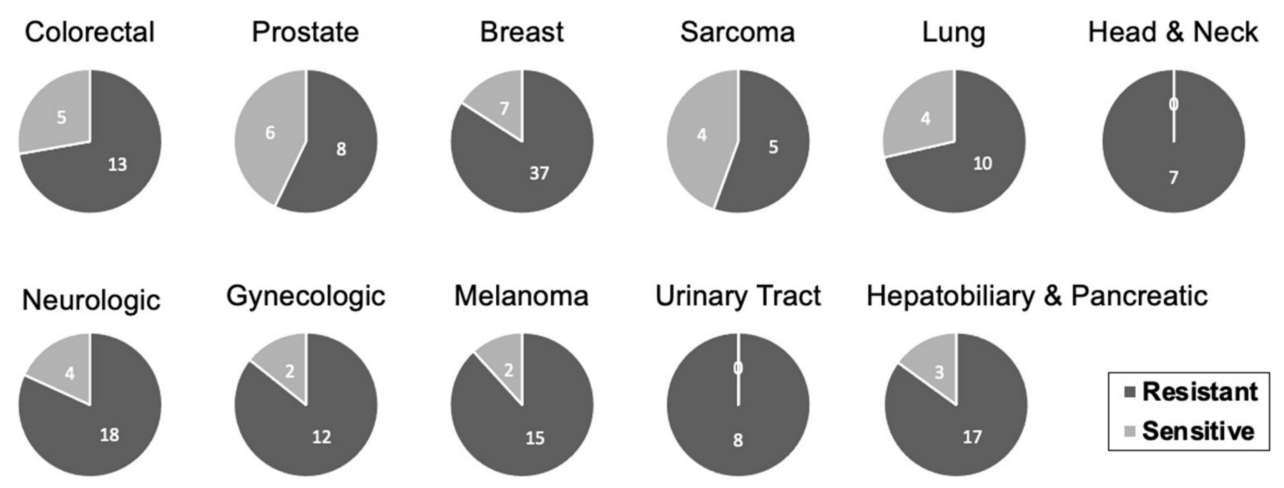

Figure 7. Cancer-specific response to chemotherapy. Each response represents a single experimental outcome. A larger fraction of all cell-lines showed resistance to chemotherapy. Cell-lines that were not frequently studied were categorized under an organ system. Sarcoma includes osteosarcoma, chondrosarcoma, and fibrosarcoma cell-lines. Head and neck cancers include head and neck squamous cell carcinoma, adenoid cystic carcinoma, and ameloblastoma cell-lines. Urinary tract cancers include renal cell carcinoma, renal cell carcinoma bone metastasis, and bladder cancer. Gynecologic malignancies include ovarian and cervical cancer cell-lines. Neurologic cancers include glioblastoma multiforme, neuroblastoma and astrocytoma cell-lines. Hepatobiliary and pancreatic cancers include hepatocellular, biliary tract, and pancreatic cancer cell-lines. 
We identified 42 publications from our cohort that specifically studied chemotherapy resistance in 3D cultures, and similar numbers of studies used in scaffold-based cultures and non-scaffold-based cultures ( $53 \%$ vs. $47 \%$ ). On further investigation, the studies where scaffold-based 3D cultures were used, a much greater percentage of studies used native materials $(72 \%)$ compared to non-native materials (28\%). Similar to the cohort of studies concerning biomimicry of tumour culture, collagen and alginate appear to be the most frequently used materials for native and non-native scaffolds. This noteworthy finding could be due to native ECM proteins being deemed more biomimetic as a 3D scaffold, with materials such as collagen used extensively. Collagen type I is found in the dense fibrotic tissue and the tumour microenvironment, and by using this material, studies report the use of native materials to be more consistent between in vitro and in vivo findings (Figure 8).

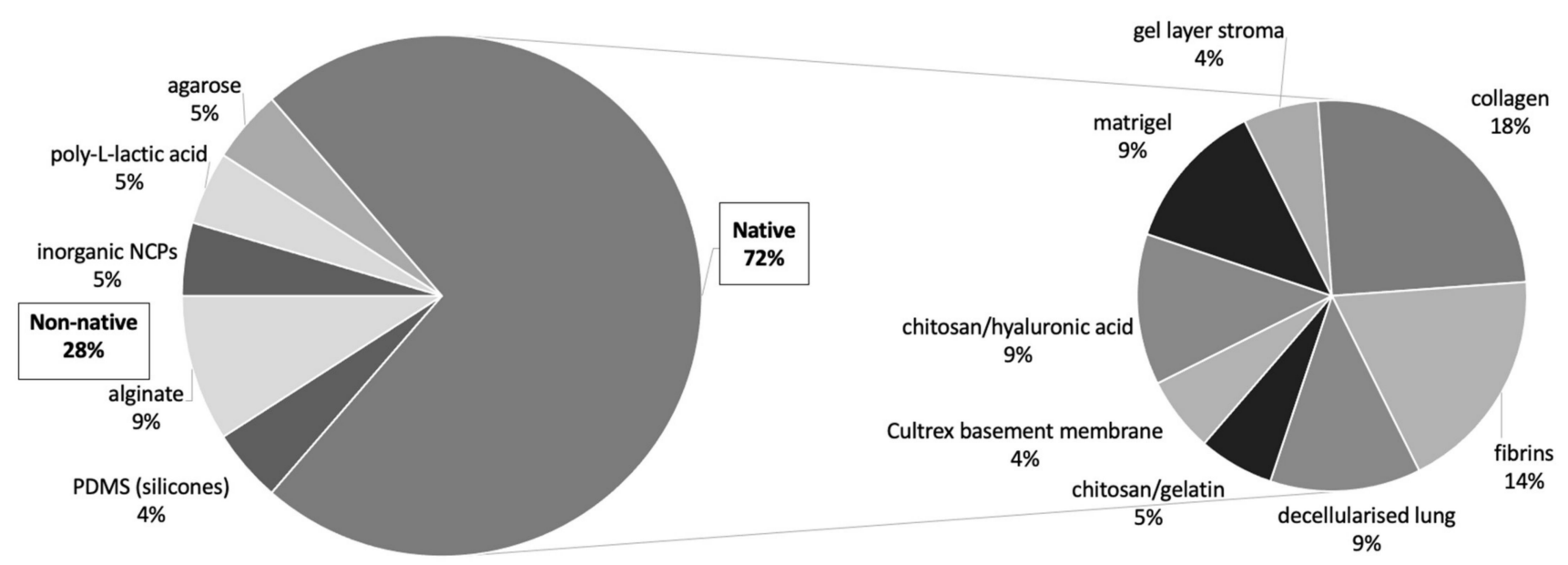

Figure 8. Drug resistance studies: scaffold types. Proportional representation of native and non-native scaffold types used in $3 \mathrm{D}$ in vitro tumour models in studies regarding drug resistance with preference towards native scaffold materials over non-native material choices.

\subsection{Invasion vs. Migration Are Distinctly Different but Related Processes in Cancer Growth and Metastasis}

When describing cancer progression and metastasis, invasion and migration often go hand in hand and are described as parts of a process facilitating cancer spread. We investigated the evidence within the scope of this review for the definition and measurable markers used for invasion and migration, and whether these were distinct to one or the other process. 16 publications $[24,25,28,32,36,47,49,55,62,82,85,89,92,99,112,124]$ were identified which described the process of invasion or migration or both. Techniques of measuring aspects of migration and invasion involved mostly imaging assays, with a small number of publications conducting quantitative RT-PCR and immunofluorescent staining on various genetic expression and cell surface markers for each of the processes (Table 3).

Migration imaging assays describe the process as the movement of tumour cells from one position to another, for example across porous membranes, movement within the tumour spheroids or out into the surrounding matrix in an in vitro setting. The morphology of cancer invasion is described in a more aggressive manner, with terms such as invasive, spiky projections and invadopodias into the surrounding ECM. Fibronectin coding genes were found to be up-regulated in studies describing cancer cell migration and various EMT markers such as vimentin, E-cadherin, MMP2 and MMP9, which were all associated with and used to measure cellular invasion. Only invasion is described in an in vivo setting, which has been duly noted in multiple publications. Florczyk et al. described the two cellular processes as, "invasion in vivo and migration in vitro by effective degradation of ECM" [89]. Therefore, it would appear that migration is a process exclusively observed and described in the in vitro setting, whereas invasion can be observed and measured 
in both in vitro and in vivo. We can also draw the conclusion that cancer invasion is heavily associated with EMT because the majority of PCR and immunofluorescent staining markers used to measure invasion are also used for assessing EMT in cancer cells. From the 16 publications included in this review we can infer that both migration and invasion describe the process of movement of cells, but migration refers to movement only and invasion implies additional intrinsic cellular changes and remodelling of ECM components.

Table 3. Measurable markers of migration and invasion. Descriptors of migration are restrict to cell movement, whereas descriptors of invasion include the phrase "aggressive". (IF- immunofluorescent. PCR- polymerase chain reaction).

\begin{tabular}{|c|c|c|}
\hline Measuring Technique & Migration & Invasion \\
\hline Imaging (14 publications) & $\begin{array}{ll}\text { - } & \text { Transwell migration assay across } \\
\text { - } & \text { Porous membrane. } \\
\text { - } & \text { Cell movement out of spheroid. } \\
\text { - } & \text { Movement into surrounding gel matrix. } \\
\text { - } & \text { Movement of single cell into aggregates. } \\
\text { - } & \text { Motility assay. } \\
\text { - } & \text { Movement on ECM/gelatin, dispersion of cells } \\
& \text { from a solid and ameboid migration pattern. }\end{array}$ & $\begin{array}{l}\text { - Invaded cells from spheroid into } \\
\text { surrounding collagen/basement } \\
\text { membrane/invasion matrix ECM. } \\
\text { - } \quad \text { Boyden chamber invasion assay. } \\
\text { Invasive/spiky } \\
\text { projections/invadopodias. }\end{array}$ \\
\hline $\begin{array}{l}\text { qPCR/protein microarray } \\
\text { (3 publications })\end{array}$ & FAK. c-Src. FN1 & $\begin{array}{l}\text { MMP-2, MMP-9. TWIST 1. MRTK. AXL. } \\
\text { SNAIL1. SNAIL2 }\end{array}$ \\
\hline IF stain (2 publications) & $\mathrm{n} / \mathrm{a}$ & vimentin. E-cadherin. \\
\hline Related to EMT & $\mathrm{n} / \mathrm{a}$ & $\begin{array}{l}\text { Yes (PCR and IF stain markers all notable } \\
\text { EMT markers) }\end{array}$ \\
\hline Measured in vivo/in vitro & In vitro & in vivo and in vitro \\
\hline
\end{tabular}

\section{Discussion}

It is important to consider the average range of oxygen concentration in physiologically and pathologically hypoxic tissues when conducting in vitro tumour cultures. Normal tissue oxygen saturation is based on $\mathrm{pO}_{2}$, and is distinct from ambient atmospheric oxygen, which is $21 \%$. Tissue normoxia, or physiological hypoxia, ranges between $3-7 \%$, thus when conducting comparisons of hypoxic vs normoxic cultures in cancer studies, a more appropriate choice for hypoxia level should be no higher than $2 \%$ oxygen and normoxia control samples should be conducted within the "normal" physiological oxygen levels to truly represent the in vivo tumour and stromal microenvironments [67].

To highlight the significance of ranges of hypoxia, over a fifth $(22 \%)$ of studies included in this review explored tumour hypoxia using 3\% oxygen or higher for the hypoxic samples, and furthermore $5 \%$ of studies [22,33,47,51] used $>7 \%$ oxygen which is in fact a higher level than the average normal tissue oxygen concentration. Furthermore, the oxygen level for normoxic control samples used in 51 studies, at atmospheric oxygen concentration (17-21\%), are far higher than physiological tissue normoxia encountered in previous literature (3-7\%). By conducting studies at higher oxygen levels than that of the average range for pathological hypoxia, one could alter the expression of HIFs. HIFs and its wide range of transcriptional activities, for example upregulation of pro-angiogenic genes such as VEGF and IL8 and downregulation of angiogenic inhibitors such as angiostatin and endostatin, are crucial in tumorigenesis. Hitherto, the oxygen range required for HIF expression and regulation should be taken into account to produce a truly biomimetic in vitro tumour models $[43,125]$. Although the half maximum expression of HIFs has been documented to occur between 1.5-2\% oxygen [67], we must also take into account that in some tumour cells, HIF expression can persist at a much lower oxygen level compared to normal cells due to their constitutive or genetic changes which lead to altered regulation of the expression of HIFs. 
Apart from the level of hypoxia involved in these in vitro studies, the length of exposure also plays a vital role for the biomimicry of these tumour models. There is evidence to suggest that acute hypoxia is more likely to contribute to the malignant progression of tumour cells when compared with chronic hypoxia, meaning that an exposure period of $72 \mathrm{~h}$ or less used by the majority $(71 \%)$ of tumour models included in this review is a sufficient period for hypoxic exposure for malignant progression of most cancer cells. HIF1's activation has been shown to upregulate EMT within $18 \mathrm{hrs}$ of exposure to $1 \%$ oxygen and upregulation of angiogenesis related markers can be seen within 2 to $4 \mathrm{~h} \mathrm{[126].} \mathrm{One} \mathrm{study}$ we encountered explored cycling hypoxia and reoxygenation in their tumour cultures [61]. Although evidence does show acute hypoxia exposure is sufficient in tumorigenesis, the repeated cycles of hypoxia/reoxygenation have also been linked with increased angiogenesis, and genetic instability due to induction of DNA damage and impaired DNA repair mechanisms [127].

In this review we can deduce that $3 \mathrm{D}$ tumour models have shown to be a better representation of the in vivo tumour microenvironment regardless if they are scaffold based or rely upon cell-generated ECM deposition to develop 3D matrix, when compared to 2D cultures. Multicellular spheroids and ECM/scaffold-based tumour cultures have similarities in their shared three-dimensional nature in terms of presence of hypoxic regions and their effects on tumour growth and metastasis. Both scaffold and non-scaffold-based tumour cultures demonstrate that tumour cells play a significant role in the secretion of various ECM proteins such as collagen and fibronectin. There is significant data to suggest that non scaffold based in vitro cancer cell cultures, with an absence of extracellular ECM have a less significant effect on the biomimetic properties of the tumour models in terms of hypoxia driven gene expressions, cell ECM interaction driven growth and invasion, and malignant progression. The role of ECM in facilitating tumour invasion and migration is still not fully understood, however evidence has shown that ECM remodelling and infiltration of ECM is strongly primed by various soluble factors by the infiltrating tumour cells [128]. This would suggest that the indifference between the proportion of scaffold and non-scaffold based studies in this review could be explained by the innate ECM secretion and alteration abilities of the tumour cells.

However, when we analysed the studies exclusively exploring the role of 3D tumour models on EMT, the majority of studies involved scaffold based cultures in comparison with studies looking at biomimicry as a generic theme. ECM components such as collagens, fibronectins, and hyaluronic acid have been shown to play a crucial regulatory role in the EMT signalling pathways. Studies have shown growth factors such as TGF-B, which is present in or sequestered by ECM components, via the TBG-B-ECM axis increases expression of pathways for EMT execution in a dependent manner. Overall, ECM not only provides a structurally supportive role in cancer growth and invasion, but also ECM derived signals provide critical anchor points involved in EMT during the tumorigenesis process and the fine-tuned interaction between the ECM and tumour cells have a vital role in pathogenesis of cancer [129]. Therefore, the use of scaffold based in vitro tumour cultures for the study of EMT specifically is reported to enhance the EMT process given the involvement of ECM in this process. This does not undermine the role of cell-generated ECM in non-scaffold based, however the level of pre-existing ECM has a strong positive correlation with enhanced EMT in tumour models.

CSCs have been isolated and characterised from numerous types of solid cancers such as breast, colorectal, and hepatocellular carcinomas. Their role in tumorigenesis and metastasis has been described in previous literature and their self-renewal, replicative and differentiative abilities via common signalling pathways have been hypothesised to be the basis for metastatic tumour growth [130]. This review highlighted the upregulation of CSC markers in 3D in vitro tumour constructs when compared with 2D, a key feature of cancer evolution, thus reiterating the supporting evidence for enhanced biomimicry features of $3 \mathrm{D}$ tumour models compared to 2D cultures. 
The preference of native material over non-native material for scaffold based in vitro tumour models in drug resistance studies is the logical approach since the purpose of these experiments are for prediction of in vivo therapy response in an in vitro laboratory setting. Therefore, in order to recapitulate the natural in vivo tumour microenvironment, the choice of natively occurring scaffold material is an obvious preference.

Response to all therapy classes conveyed a trend of increased resistance to therapy in $3 \mathrm{D}$ in vitro tumour cultures compared to $2 \mathrm{D}$ cultures. Furthermore, five out of six of the chemotherapy classes expressed congruent response of increased resistance to therapy in all experimental setups in 3D compared to 2D. Pro-apoptotic agents stood out showing almost even-handed response. We uncovered that 9/10 experimental setups expressing sensitivity to proapoptotic agents used the drug triapizamine. Tirapazamine, a hypoxia- activated agent, showed increased sensitivity in 3D tumour in all the studies which involved the drug. Due to the presence of intrinsic hypoxic cores in 3D tumour constructs, tirapazamine targets hypoxic regions of the tumour, therefore is highly sensitive in such tumour cultures compared to 2D tumour cultures which lack hypoxic regions [131]. The targeted therapy class displayed a relatively high count of sensitive responses compared to other classes of therapy [56]. As this group includes unclassified chemotherapeutic agents understudied novel therapies and enzyme targets, it is hard to identify the reason of the unusual cellular response to these therapies. Further research is encouraged to promote understanding of these drugs, and their efficacy in vivo, since their anti-tumour effect in more biomimetic 3D models is favourable.

The proportional increase in chemosensitivity of prostate cancer and sarcomas can be accounted for by the multiple specific enzymes targeting novel chemotherapy agents tested in each of the publications compared to other cancer types studied in other publications. When sarcoma cell lines responses to novel targeted therapy DZNep compared to a classical chemotherapy agent cisplatin, all cell lines displayed chemosensitivity to DZNep and resistance to cisplatin [80]. The limited literature regarding these novel chemotherapy agents demonstrates the need for further in depth understanding into these novel chemotherapy agents is required to evaluate the outcomes from studies which involve novel experimental chemo agents.

The increased drug resistance in 3D tumour cultures compared to 2D culture systems is not only owing to its oxygen diffusion gradient. The presence of hypoxia is a well-known factor responsible for drug resistance via several difference mechanisms such as hypoxia induced G0 cell cycle arrest [132]. The increased CSC markers expression should also be considered as a factor in increased drug resistance in 3D cancer cultures as the presence of CSCs have been shown to increase chemoresistance and tumorigenicity [133]. Therefore, cancer chemoresistance should be studied as a multifactorial, multi-causative feature taking into account various key aspects of the tumour microenvironment such as scaffold material, hypoxia level and the involvements of CSCs.

Cell migration in the non-malignant setting usually refers to the orchestrated movement of cells in a particular direction to a specific location [134]. Cell invasion has been defined by various publications with an example from Nature Research stating invasion as "the ability of cells to become motile and to navigate through the ECM within a tissue or to infiltrate neighboring tissues" [135]. Nevertheless, the common theme amongst publications defining cell invasion is the pertinent role it has in cancer progression and metastasis. Many authors describe cell migration to be the first step of cancer invasion into the adjacent surrounding which can be supported by the presence of cellular movement from the 3D tumour spheroids into the surrounding ECM and subsequently forming invasive projections via various cell-ECM interactions [136]. Therefore, the two seemingly distinct cellular processes are closely related when it comes to cancer progression and spread, so one could argue that invasion and migration ought to be investigated as stages of the same process rather than two separate cellular actions. There is also evidence to support the concept of migration being a benign process whereas invasion is closely related to EMT therefore possessing the hallmarks of malignant cellular behaviour. 
It is crucial to recognise possible reporting biases which may have resulted during the course of this comprehensive review. Publication, time lag and language biases were noted since this review deemed only full text publications up until 28 May 2020 in English language eligible for analysis. Outcome reporting bias was also taken into account and two independent investigators were involved in the data collection process separately, without influence from external parties. Nevertheless, taking into account of possible biases, this report should still show a relative comprehensive analysis of the topic due to the inclusive search and analysis methods.

\section{Conclusions}

To conclude, this comprehensive systematic review has analysed in depth the published outcomes in existing literature of the role of 3D cell culture techniques and the corresponding physiological hypoxia on cancer cell behaviour, in particular focusing on growth, invasion, EMT and response to therapeutic interventions. Hypoxia level and duration is a crucial consideration when partaking in in vitro tumour hypoxia studies and must reflect the tissue oxygen concentrations. Whether to use scaffold-based tumour models should be carefully considered when exploring the effects of 3D tumour models on EMT and furthermore the choice of scaffolds in drug resistance studies highlights the importance for in vitro tumour models to recapitulate the in vivo tumour microenvironment. Migration and invasion are distinct but related processes both play crucial roles in cancer progression and metastasis. The development of and optimisation of in vitro 3D tumour models using a variety of microenvironments is essential in the study of cancer growth and progression, and advances in cancer treatments.

Author Contributions: Conceptualization, Y.L., Z.M., W.A. and U.C.; methodology, Y.L., Z.M., W.A. and U.C.; formal analysis, Y.L., Z.M., W.A. and U.C.; investigation, Y.L., Z.M., and W.A.; data curation, Y.L., Z.M. and W.A.; writing-original draft preparation, Y.L.; writing-review and editing, Y.L., Z.M., W.A. and U.C.; supervision, U.C.; All authors have read and agreed to the published version of the manuscript.

Funding: This research received no external funding.

Institutional Review Board Statement: Not applicable.

Informed Consent Statement: Not applicable.

Acknowledgments: The authors would like to thank University College London for ongoing support.

Conflicts of Interest: The authors declare no conflict of interest.

\section{References}

1. Office for National Statistics. Deaths Registered in England and Wales. 2015. Available online: https://www.ons.gov. uk/peoplepopulationandcommunity/birthsdeathsandmarriages/deaths/bulletins/deathsregistrationsummarytables/2019 (accessed on 1 June 2020).

2. National Cancer Institute. National Cancer Act of 1971. 1971. Available online: https://dtp.cancer.gov/timeline/flash/ milestones/M4_Nixon.htm (accessed on 1 June 2020).

3. Ambrose, C.T. An amended history of tissue culture: Concerning Harrison, Burrows, Mall, and Carrel. J. Med. Biogr. 2019, 27, 95-102. [CrossRef] [PubMed]

4. Benien, P.; Swami, A. 3D tumor models: History, advances and future perspectives. Future Oncol. 2014, 10, 1311-1327. [CrossRef] [PubMed]

5. Nunes, A.S.; Barros, A.S.; Costa, E.C.; Moreira, A.F.; Correia, I.J. 3D tumor spheroids as in vitro models to mimic in vivo human solid tumors resistance to therapeutic drugs. Biotechnol. Bioeng. 2019, 116, 206-226. [CrossRef] [PubMed]

6. $\quad$ Pettersen, E.O.; Ebbesen, P.; Gieling, R.G.; Williams, K.J.; Dubois, L.; Lambin, P.; Ward, C.; Meehan, J.; Kunkler, I.H.; Langdon, S.P.; et al. Targeting tumour hypoxia to prevent cancer metastasis. From biology, biosensing and technology to drug development: The METOXIA consortium. J. Enzym. Inhib. Med. Chem. 2015, 30, 689-721. [CrossRef]

7. Nyga, A.; Cheema, U.; Loizidou, M. 3D tumour models: Novel in vitro approaches to cancer studies. J. Cell Commun. Signal. 2011, 5, 239-248. [CrossRef]

8. Peck, Y.; Wang, D.A. Three-dimensionally engineered biomimetic tissue models for in vitro drug evaluation: Delivery, efficacy and toxicity. Expert Opin. Drug Deliv. 2013, 10,369-383. [CrossRef] 
9. Zhan, Y.S.; Duchamp, M.; Oklu, R.; Ellisen, L.W.; Langer, R.; Khademhosseini, A. Bioprinting the Cancer Microenvironment. ACS Biomater. Sci. Eng. 2016, 2, 1710-1721. [CrossRef] [PubMed]

10. Leek, R.; Grimes, D.R.; Harris, A.L.; McIntyre, A. Methods: Using Three-Dimensional Culture (Spheroids) as an In Vitro Model of Tumour Hypoxia. In Tumor Microenvironment: Study Protocols; Koumenis, C., Coussens, L.M., Giaccia, A., Hammond, E., Eds.; Springer: Berlin/Heidelberg, Germany, 2016; Volume 899, pp. 167-196.

11. Zhou, Y. Understanding the cancer/tumor biology from 2D to 3D. J. Thorac. Dis. 2016, 8, E1484-E1486. [CrossRef] [PubMed]

12. Drost, J.; Clevers, H. Organoids in cancer research. Nat. Rev. Cancer 2018, 18, 407-418. [CrossRef]

13. Nyga, A.; Loizidou, M.; Emberton, M.; Cheema, U. A novel tissue engineered three-dimensional in vitro colorectal cancer model. Acta Biomater. 2013, 9, 7917-7926. [CrossRef] [PubMed]

14. Whitman, N.A.; Lin, Z.W.; Kenney, R.M.; Albertini, L.; Lockett, M.R. Hypoxia differentially regulates estrogen receptor alpha in 2D and 3D culture formats. Arch. Biochem. Biophys. 2019, 671, 8-17. [CrossRef] [PubMed]

15. Wang, Y.; Mirza, S.; Wu, S.; Zeng, J.; Shi, W.; Band, H.; Band, V.; Duan, B. 3D hydrogel breast cancer models for studying the effects of hypoxia on epithelial to mesenchymal transition. Oncotarget 2018, 9, 32191-32203. [CrossRef]

16. Depping, R.; von Fallois, M.; Landesman, Y.; Kosyna, F.K. The Nuclear Export Inhibitor Selinexor Inhibits Hypoxia Signaling Pathways And 3D Spheroid Growth Of Cancer Cells. Oncotargets Ther. 2019, 12, 8387-8399. [CrossRef] [PubMed]

17. DelNero, P.; Lane, M.; Verbridge, S.S.; Kwee, B.; Kermani, P.; Hempstead, B.; Stroock, A.; Fischbach, C. 3D culture broadly regulates tumor cell hypoxia response and angiogenesis via pro-inflammatory pathways. Biomaterials 2015, 55, 110-118. [CrossRef]

18. Liu, X.Q.; Kiefl, R.; Roskopf, C.; Tian, F.; Huber, R.M. Interactions among lung cancer cells, fibroblasts, and macrophages in 3D co-cultures and the impact on MMP-1 and VEGF expression. PLoS ONE 2016, 11, e0156268. [CrossRef] [PubMed]

19. Musah-Eroje, A.; Watson, S. A novel 3D in vitro model of glioblastoma reveals resistance to temozolomide which was potentiated by hypoxia. J. Neuro Oncol. 2019, 142, 231-240. [CrossRef] [PubMed]

20. Pavel, M.; Renna, M.; Park, S.J.; Menzies, F.M.; Ricketts, T.; Fullgrabe, J.; Ashkenazi, A.; Frake, R.A.; Lombarte, A.C.; Bento, C.F.; et al. Contact inhibition controls cell survival and proliferation via YAP/TAZ-autophagy axis. Nat. Commun. 2018, 9, 2961. [CrossRef]

21. Blandin, A.F.; Durand, A.; Litzler, M.; Tripp, A.; Guerin, E.; Ruhland, E.; Obrecht, A.; Keime, C.; Fuchs, Q.; Reita, D.; et al. Hypoxic Environment and Paired Hierarchical 3D and 2D Models of Pediatric H3.3-Mutated Gliomas Recreate the Patient Tumor Complexity. Cancers 2019, 11, 1875. [CrossRef]

22. Sethumadhavan, S.; Silva, M.; Philbrook, P.; Nguyen, T.; Hatfield, S.M.; Ohta, A.; Sitkovsky, M.V. Hypoxia and hypoxia-inducible factor (HIF) downregulate antigen-presenting MHC class I molecules limiting tumor cell recognition by T cells. PLoS ONE 2017, 12, e0187314.

23. Hirst, J.; Pathak, H.B.; Hyter, S.; Pessetto, Z.Y.; Ly, T.; Graw, S.; Koestler, D.C.; Krieg, A.J.; Roby, K.F.; Godwin, A.K. Licofelone enhances the efficacy of paclitaxel in ovarian cancer by reversing drug resistance and tumor stem-like properties. Cancer Res. 2018, 78, 4370-4385. [CrossRef]

24. Hugo, H.J.; Gunasinghe, N.P.A.D.; Hollier, B.G.; Tanaka, T.; Blick, T.; Toh, A.; Hill, P.; Gilles, C.; Waltham, M.; Thompson, E.W. Epithelial requirement for in vitro proliferation and xenograft growth and metastasis of MDA-MB-468 human breast cancer cells: Oncogenic rather than tumor-suppressive role of E-cadherin. Breast Cancer Res. 2017, 19, 86. [CrossRef]

25. Godet, I.; Shin, Y.J.; Ju, J.A.; Ye, I.C.; Wang, G.N.; Gilkes, D.M. Fate-mapping post-hypoxic tumor cells reveals a ROS-resistant phenotype that promotes metastasis. Nat. Commun. 2019, 10, 4862. [CrossRef]

26. Ahmed, E.M.; Bandopadhyay, G.; Coyle, B.; Grabowska, A. A HIF-independent, CD133-mediated mechanism of cisplatin resistance in glioblastoma cells. Cell. Oncol. 2018, 41,319-328. [CrossRef]

27. Jarman, E.J.; Ward, C.; Turnbull, A.K.; Martinez-Perez, C.; Meehan, J.; Xintaropoulou, C.; Sims, A.H.; Langdon, S.P. HER2 regulates HIF-2 $\alpha$ and drives an increased hypoxic response in breast cancer. Breast Cancer Res. 2019, 21, 10. [CrossRef] [PubMed]

28. Ju, J.L.A.; Godet, I.; Ye, I.C.; Byun, J.; Jayatilaka, H.; Lee, S.J.; Xiang, L.S.; Samanta, D.; Lee, M.H.; Wu, P.H.; et al. Hypoxia Selectively Enhances Integrin alpha(5)beta(1) Receptor Expression in Breast Cancer to Promote Metastasis. Mol. Cancer Res. 2017, 15, 723-734. [CrossRef]

29. Blick, C.; Ramachandran, A.; Wigfield, S.; McCormick, R.; Jubb, A.; Buffa, F.M.; Turley, H.; Knowles, M.A.; Cranston, D.; Catto, J.; et al. Hypoxia regulates FGFR3 expression via HIF-1 $\alpha$ and miR-100 and contributes to cell survival in non-muscle invasive bladder cancer. Br. J. Cancer 2013, 109, 50-59. [CrossRef] [PubMed]

30. Stewart, G.D.; Nanda, J.; Katz, E.; Bowman, K.J.; Christie, J.G.; Brown, D.J.G.; McLaren, D.B.; Riddick, A.C.P.; Ross, J.A.; Jones, G.D.D.; et al. DNA strand breaks and hypoxia response inhibition mediate the radiosensitisation effect of nitric oxide donors on prostate cancer under varying oxygen conditions. Biochem. Pharmacol. 2011, 81, 203-210. [CrossRef]

31. Jiang, X.Y.; Wang, C.; Fitch, S.; Yang, F. Targeting Tumor Hypoxia Using Nanoparticle-engineered CXCR4-overexpressing Adipose-derived Stem Cells. Theranostics 2018, 8, 1350-1360. [CrossRef] [PubMed]

32. Levin, V.A.; Panchabhai, S.; Shen, L.; Baggerly, K.A. Protein and phosphoprotein levels in glioma and adenocarcinoma cell lines grown in normoxia and hypoxia in monolayer and three-dimensional cultures. Proteome Sci. 2012, 10, 5. [CrossRef]

33. Zheng, J.; Liu, Y.; Song, F.; Jiao, L.; Wu, Y.; Peng, X. A nitroreductase-activatable near-infrared theranostic photosensitizer for photodynamic therapy under mild hypoxia. Chem. Commun. 2020, 24, 5819-5822. [CrossRef] 
34. Hedley, B.; Allan, A.; Chu, J.; Beausoleil, M.; Boasie, A.; Ormond, D.G.; Xenocostas, A. Recombinant human erythropoietin $(\mathrm{rHuEPO})$ in combination with chemotherapy increases breast cancer metastasis in preclinical mouse models. Clin. Exp. Metastasis 2011, 28, 160-161.

35. Cheng, Y.Y.; Wang, Y.; Van Zandwijk, N.; Reid, G. A 3d spheroid culture represents an improved in vitro model of malignant plural mesothelioma (MPM). J. Thorac. Oncol. 2017, 12 (Suppl. 2), S2266. [CrossRef]

36. Vinci, M.; Box, C.; Zimmermann, M.; Eccles, S.A. Tumor spheroid-based migration assays for evaluation of therapeutic agents. Methods Mol. Biol. 2013, 986, 253-266. [PubMed]

37. Velliou, E.G.; Dos Santos, S.B.; Papathanasiou, M.M.; Fuentes-Gari, M.; Misener, R.; Panoskaltsis, N.; Pistikopoulos, E.N.; Mantalaris, A. Towards unravelling the kinetics of an acute myeloid leukaemia model system under oxidative and starvation stress: A comparison between two- and three-dimensional cultures. Bioprocess Biosyst. Eng. 2015, 38, 1589-1600. [CrossRef] [PubMed]

38. Van Rixel, V.H.S.; Ramu, V.; Auyeung, A.B.; Beztsinna, N.; Leger, D.Y.; Lameijer, L.N.; Hilt, S.T.; Le Devedec, S.E.; Yildiz, T.; Betancourt, T.; et al. Photo-Uncaging of a Microtubule-Targeted Rigidin Analogue in Hypoxic Cancer Cells and in a Xenograft Mouse Model. J. Am. Chem. Soc. 2019, 141, 18444-18454. [CrossRef]

39. Sun, L.L.; Li, G.Y.; Chen, X.; Chen, Y.; Jin, C.Z.; Ji, L.N.; Chao, H. Azo-Based Iridium(III) Complexes as Multicolor Phosphorescent Probes to Detect Hypoxia in 3D Multicellular Tumor Spheroids. Sci. Rep. 2015, 5, 14837. [CrossRef] [PubMed]

40. Simko, V.; Takacova, M.; Debreova, M.; Laposova, K.; Ondriskova-Panisova, E.; Pastorekova, S.; Csaderova, L.; Pastorek, J. Dexamethasone downregulates expression of carbonic anhydrase IX via HIF-1 alpha and NF-kappa B-dependent mechanisms. Int. J. Oncol. 2016, 49, 1277-1288. [CrossRef]

41. Schutze, F.; Rohrig, F.; Vorlova, S.; Gatzner, S.; Kuhn, A.; Ergun, S.; Henke, E. Inhibition of Lysyl Oxidases Improves Drug Diffusion and Increases Efficacy of Cytotoxic Treatment in 3D Tumor Models. Sci. Rep. 2015, 5, 17576. [CrossRef] [PubMed]

42. Qin, Y.; Roszik, J.; Chattopadhyay, C.; Hashimoto, Y.; Liu, C.W.; Cooper, Z.A.; Wargo, J.A.; Hwu, P.; Ekmekcioglu, S.; Grimm, E.A. Hypoxia-Driven Mechanism of Vemurafenib Resistance in Melanoma. Mol. Cancer Ther. 2016, 15, 2442-2454. [CrossRef] [PubMed]

43. Parks, S.K.; Cormerais, Y.; Pouyssegur, J. Hypoxia and cellular metabolism in tumour pathophysiology. J. Physiol. 2017, 595, 2439-2450. [CrossRef]

44. Palma, A.; Grande, S.; Luciani, A.M.; Mlynarik, V.; Guidoni, L.; Viti, V.; Rosi, A. Metabolic study of breast MCF-7 tumor spheroids after gamma irradiation by ${ }^{1} \mathrm{H}$ NMR spectroscopy and microimaging. Front. Oncol. 2016, 6, 105. [CrossRef]

45. Ornell, K.J.; Mistretta, K.S.; Newman, E.; Ralston, C.Q.; Coburn, J.M. Three-Dimensional, Scaffolded Tumor Model to Study Cell-Driven Microenvironment Effects and Therapeutic Responses. ACS Biomater. Sci. Eng. 2019, 5, 6742-6754. [CrossRef] [PubMed]

46. Nakayama, T.; Otsuka, S.; Kobayashi, T.; Okajima, H.; Matsumoto, K.; Hagiya, Y.; Inoue, K.; Shuin, T.; Nakajima, M.; Tanaka, T.; et al. Dormant cancer cells accumulate high protoporphyrin IX levels and are sensitive to 5-aminolevulinic acid-based photodynamic therapy. Sci. Rep. 2016, 6, 36478. [CrossRef]

47. Meehan, J.; Ward, C.; Turnbull, A.; Bukowski-Wills, J.; Finch, A.J.; Jarman, E.J.; Xintaropoulou, C.; Martinez-Perez, C.; Gray, M.; Pearson, M.; et al. Inhibition of $\mathrm{pH}$ regulation as a therapeutic strategy in hypoxic human breast cancer cells. Oncotarget 2017, 8, 42857-42875. [CrossRef]

48. Marin-Hernandez, A.; Gallardo-Perez, J.C.; Hernandez-Resendiz, I.; Del Mazo-Monsalvo, I.; Robledo-Cadena, D.X.; MorenoSanchez, R.; Rodriguez-Enriquez, S. Hypoglycemia Enhances Epithelial-Mesenchymal Transition and Invasiveness, and Restrains the Warburg Phenotype, in Hypoxic HeLa Cell Cultures and Microspheroids. J. Cell. Physiol. 2017, 232, 1346-1359. [CrossRef]

49. Li, X.B.; Hattori, A.; Takahashi, S.; Goto, Y.; Harada, H.; Kakeya, H. Ubiquitin carboxyl-terminal hydrolase L1 promotes hypoxia-inducible factor 1-dependent tumor cell malignancy in spheroid models. Cancer Sci. 2020, 111, 239-252. [CrossRef]

50. Lee, J.W.; Shin, D.H.; Roh, J.L. Development of an in vitro cell-sheet cancer model for chemotherapeutic screening. Theranostics 2018, 8, 3964-3973. [CrossRef] [PubMed]

51. Kulasinghe, A.; Perry, C.; Warkiani, M.E.; Blick, T.; Davies, A.; O’Byrne, K.; Thompson, E.W.; Nelson, C.C.; Vela, I.; Punyadeera, C. Short term ex-vivo expansion of circulating head and neck tumour cells. Oncotarget 2016, 7, 60101-60109. [CrossRef]

52. Kinoshita, T.; Higuchi, H.; Ayano Kabashima, N.; Sakai, G.; Hamamoto, Y.; Takaishi, H.; Kanai, T. Analysis of sensitivity and cell death pathways mediated by anti-cancer drugs using three-dimensional culture system. Int. J. Cancer Res. 2018, 14, 1-12. [CrossRef]

53. Kim, J.W.; Ho, W.J.; Wu, B.M. The Role of the 3D Environment in Hypoxia-induced Drug and Apoptosis Resistance. Anticancer Res. 2011, 31, 3237-3245.

54. Kieninger, J.; Tamari, Y.; Enderle, B.; Jobst, G.; Sandvik, J.A.; Pettersen, E.O.; Urban, G.A. Sensor Access to the Cellular Microenvironment Using the Sensing Cell Culture Flask. Biosensors 2018, 8, 44. [CrossRef] [PubMed]

55. Kalchman, J.; Fujioka, S.; Chung, S.; Kikkawa, Y.; Mitaka, T.; Kamm, R.D.; Tanishita, K.; Sudo, R. A three-dimensional microfluidic tumor cell migration assay to screen the effect of anti-migratory drugs and interstitial flow. Microfluid. Nanofluid. 2013, 14, 969-981. [CrossRef]

56. Jones, D.T.; Valli, A.; Haider, S.; Zhang, Q.F.; Smethurst, E.A.; Schug, Z.T.; Peck, B.; Aboagye, E.O.; Critchlow, S.E.; Schulze, A.; et al. 3D Growth of Cancer Cells Elicits Sensitivity to Kinase Inhibitors but Not Lipid Metabolism Modifiers. Mol. Cancer Ther. 2019, 18, 376-388. [CrossRef] [PubMed] 
57. Jenkins, J.; Papkovsky, D.B.; Dmitriev, R.I. The Ca2+/Mn2+-transporting SPCA2 pump is regulated by oxygen and cell density in colon cancer cells. Biochem. J. 2016, 473, 2507-2518. [CrossRef] [PubMed]

58. Dubois, F.; Jean-Jacques, B.; Roberge, H.; Benard, M.; Galas, L.; Schapman, D.; Elie, N.; Goux, D.; Keller, M.; Maille, E.; et al. A role for RASSF1A in tunneling nanotube formation between cells through GEFH1/Rab11 pathway control. Cell Commun. Signal. 2018, 16, 66. [CrossRef] [PubMed]

59. Czarnecka, A.M.; Solarek, W.; Kornakiewicz, A.; Szczylik, C. Tyrosine kinase inhibitors target cancer stem cells in renal cell cancer. Oncol. Rep. 2016, 35, 1433-1442. [CrossRef] [PubMed]

60. Cox, M.C.; Deng, C.Y.; Naler, L.B.; Lu, C.; Verbridge, S.S. Effects of Culture Condition on Epigenomic Profiles of Brain Tumor Cells. ACS Biomater. Sci. Eng. 2019, 5, 1544-1552. [CrossRef] [PubMed]

61. Bhatia, M.; Lovitt, C.J.; Raninga, P.V.; Avery, V.M.; Di Trapani, G.; Tonissen, K.F. Expression of the thioredoxin system in an in vivo-like cancer cell environment upon auranofin treatment. Eur. J. Cell Biol. 2016, 95, 378-388. [CrossRef]

62. Benton, G.; DeGray, G.; Kleinman, H.K.; George, J.; Arnaoutova, I. In vitro microtumors provide a physiologically predictive tool for breast cancer therapeutic screening. PLoS ONE 2015, 10, e0123312. [CrossRef]

63. Akocak, S.; Alam, M.R.; Shabana, A.M.; Sanku, R.K.K.; Vullo, D.; Thompson, H.; Swenson, E.R.; Supuran, C.T.; Hies, M.A. PEGylated Bis-Sulfonamide Carbonic Anhydrase Inhibitors Can Efficiently Control the Growth of Several Carbonic Anhydrase IX-Expressing Carcinomas. J. Med. Chem. 2016, 59, 5077-5088. [CrossRef] [PubMed]

64. Amiri, A.; Le, P.U.; Moquin, A.; Machkalyan, G.; Petrecca, K.; Gillard, J.W.; Yoganathan, N.; Maysinger, D. Inhibition of carbonic anhydrase IX in glioblastoma multiforme. Eur. J. Pharm. Biopharm. 2016, 109, 81-92. [CrossRef]

65. Cheema, U.; Brown, R.A.; Alp, B.; MacRobert, A.J. Spatially defined oxygen gradients and vascular endothelial growth factor expression in an engineered 3D cell model. Cell. Mol. Life Sci. 2008, 65, 177-186. [CrossRef] [PubMed]

66. Nunn, J.F. Evolution of the atmosphere. Proc. Geol. Assoc. 1998, 109, 1-13. [CrossRef]

67. McKeown, S.R. Defining normoxia, physoxia and hypoxia in tumours-implications for treatment response. Br. J. Radiol. 2014, 87, 20130676. [CrossRef] [PubMed]

68. Li, W.F.; Hu, X.Y.; Yang, S.T.; Wang, S.P.; Zhang, C.H.; Wang, H.; Cheng, Y.Y.; Wang, Y.W.; Liu, T.Q.; Song, K.D. A novel tissue-engineered 3D tumor model for anti-cancer drug discovery. Biofabrication 2019, 11, 015004. [CrossRef] [PubMed]

69. Boghaert, E.R.; Lu, X.; Hessler, P.E.; McGonigal, T.P.; Oleksijew, A.; Mitten, M.J.; Foster-Duke, K.; Hickson, J.A.; Santo, V.E.; Brito, C.; et al. The Volume of Three-Dimensional Cultures of Cancer Cells In Vitro Influences Transcriptional Profile Differences and Similarities with Monolayer Cultures and Xenografted Tumors. Neoplasia 2017, 19, 695-706. [CrossRef] [PubMed]

70. Yang, S.; Guo, L.J. Microencapsulation of low-passage poorly-differentiated human mucoepidermoid carcinoma cells by alginate microcapsules: In vitro profiling of angiogenesis-related molecules. Cancer Cell Int. 2017, 17, 106. [CrossRef]

71. Yang, Y.; Cheng, B.J.; Jian, H.; Chen, Z.W.; Zhao, Y.; Yu, Y.F.; Li, Z.M.; Liao, M.L.; Lu, S. XBP1-LOX axis is critical in ER stress-induced growth of lung adenocarcinoma in 3D culture. Am. J. Transl. Res. 2017, 9, 700-707. [PubMed]

72. Xu, X.X.; Liu, C.; Liu, Y.; Yang, L.; Li, N.; Guo, X.; Sun, G.W.; Ma, X.J. Enrichment of cancer stem cell-like cells by culture in alginate gel beads. J. Biotechnol. 2014, 177, 1-12. [CrossRef] [PubMed]

73. Stankevicius, V.; Kunigenas, L.; Stankunas, E.; Kuodyte, K.; Strainiene, E.; Cicenas, J.; Samalavicius, N.E.; Suziedelis, K. The expression of cancer stem cell markers in human colorectal carcinoma cells in a microenvironment dependent manner. Biochem. Biophys. Res. Commun. 2017, 484, 726-733. [CrossRef]

74. Skeberdyte, A.; Sarapiniene, I.; Aleksander-Krasko, J.; Stankevicius, V.; Suziedelis, K.; Jarmalaite, S. Dichloroacetate and Salinomycin Exert a Synergistic Cytotoxic Effect in Colorectal Cancer Cell Lines. Sci. Rep. 2018, 8, 17744. [CrossRef] [PubMed]

75. Sieh, S.; Taubenberger, A.V.; Rizzi, S.C.; Sadowski, M.; Lehman, M.L.; Rockstroh, A.; An, J.Y.; Clements, J.A.; Nelson, C.C.; Hutmacher, D.W. Phenotypic Characterization of Prostate Cancer LNCaP Cells Cultured within a Bioengineered Microenvironment. PLoS ONE 2012, 7, e0040217. [CrossRef]

76. Raju, S.R.; Gowda, K.S.M.; Jampani, A. Comparison of MDAMB-231 Cells Cultured Under Different Conditions on 2D and 3D Silk Scaffolds. Biosci. Biotechnol. Res. Commun. 2019, 12, 934-944. [CrossRef]

77. Qiu, P.H.; Qu, X.W.; Brackett, D.J.; Lerner, M.R.; Li, D.; Mao, C.B. Silica-Based Branched Hollow Microfibers as a Biomimetic Extracellular Matrix for Promoting Tumor Cell Growth In Vitro and In Vivo. Adv. Mater. 2013, 25, 2492-2496. [CrossRef]

78. Parks, S.K.; Cormerais, Y.; Durivault, J.; Pouyssegur, J. Genetic disruption of the pH(i)-regulating proteins Na+/H+ exchanger 1 (SLC9A1) and carbonic anhydrase 9 severely reduces growth of colon cancer cells. Oncotarget 2017, 8, 10225-10237. [CrossRef] [PubMed]

79. Pan, T.H.; Fong, E.L.S.; Martinez, M.; Harrington, D.A.; Lin, S.H.; Farach-Carson, M.C.; Satcher, R.L. Three-dimensional (3D) culture of bone-derived human 786-O renal cell carcinoma retains relevant clinical characteristics of bone metastases. Cancer Lett. 2015, 365, 89-95. [CrossRef]

80. Lhuissier, E.; Bazille, C.; Aury-Landas, J.; Girard, N.; Pontin, J.; Boittin, M.; Boumediene, K.; Bauge, C. Identification of an easy to use 3D culture model to investigate invasion and anticancer drug response in chondrosarcomas. BMC Cancer 2017, 17, 490. [CrossRef] [PubMed]

81. Lewis, D.M.; Blatchley, M.R.; Park, K.M.; Gerecht, S. O-2-controllable hydrogels for studying cellular responses to hypoxic gradients in three dimensions in vitro and in vivo. Nat. Protoc. 2017, 12, 1620-1638. [CrossRef] 
82. Lao, Z.; Kelly, C.J.; Yang, X.Y.; Jenkins, W.T.; Toorens, E.; Ganguly, T.; Evans, S.M.; Koch, C.J. Improved methods to generate spheroid cultures from tumor cells, tumor cells \& fibroblasts or tumor-fragments: Microenvironment, microvesicles and MiRNA. PLOS ONE 2015, 10, e0133895.

83. Kwon, J.Y.; Seo, Y.R. Genome-wide profiling induced by ionizing radiation (IR) in non-small cell lung cancer (NSCLC) grown as three-dimensional spheroid. Mol. Cell. Toxicol. 2010, 6, 229-237. [CrossRef]

84. Jiang, T.; Zhao, J.; Yu, S.; Mao, Z.; Gao, C.; Zhu, Y.; Mao, C.; Zheng, L. Untangling the response of bone tumor cells and bone forming cells to matrix stiffness and adhesion ligand density by means of hydrogels. Biomaterials 2019, 188, 130-143. [CrossRef]

85. Iwase, Y.; Nakayama, M.; Yamato, M.; Okano, T. A biomimicking tumor tissue model using hepatocellular carcinoma cell sheet in a collagen sandwich system. Anticancer Res. 2015, 35, 6481-6486. [PubMed]

86. Gorska, M.; Krzywiec, P.B.; Kuban-Jankowska, A.; Zmijewski, M.; Wozniak, M.; Wierzbicka, J.; Piotrowska, A.; Siwicka, K. Growth Inhibition of Osteosarcoma Cell Lines in 3D Cultures: Role of Nitrosative and Oxidative Stress. Anticancer Res. 2016, 36, 221-229.

87. Gamerith, G.; Rainer, J.; Huber, J.M.; Hackl, H.; Trajanoski, Z.; Koeck, S.; Lorenz, E.; Kern, J.; Kofler, R.; Kelm, J.M.; et al. 3D-cultivation of NSCLC cell lines induce gene expression alterations of key cancer-associated pathways and mimic in-vivo conditions. Oncotarget 2017, 8, 112647-112661. [CrossRef]

88. Fu, J.Q.; Fernandez, D.; Ferrer, M.; Titus, S.A.; Buehler, E.; Lal-Nag, M.A. RNAi High-Throughput Screening of Single- and Multi-Cell-Type Tumor Spheroids: A Comprehensive Analysis in Two and Three Dimensions. SLAS Discov. 2017, 22, 525-536. [CrossRef] [PubMed]

89. Florczyk, S.J.; Wang, K.; Jana, S.; Wood, D.L.; Sytsma, S.K.; Sham, J.G.; Kievit, F.M.; Zhang, M.Q. Porous chitosan-hyaluronic acid scaffolds as a mimic of glioblastoma microenvironment ECM. Biomaterials 2013, 34, 10143-10150. [CrossRef]

90. Fischbach, C.; Kong, H.J.; Hsiong, S.X.; Evangelista, M.B.; Yuen, W.; Mooney, D.J. Cancer cell angiogenic capability is regulated by 3D culture and integrin engagement. Proc. Natl. Acad. Sci. USA 2009, 106, 399-404. [CrossRef]

91. Fernekorn, U.; Hampl, J.; Weise, F.; Klett, M.; Laffert, A.; Friedel, K.; Schober, A. Microfluidic 3D HepG2 cell culture: Reproducing hepatic tumor gene and protein expression in in vitro scaffolds. Eng. Life Sci. 2015, 15, 340-350. [CrossRef]

92. Eguchi, T.; Sogawa, C.; Okusha, Y.; Uchibe, K.; Iinuma, R.; Ono, K.; Nakano, K.; Murakami, J.; Itoh, M.; Arai, K.; et al. Organoids with cancer stem cell-like properties secrete exosomes and HSP90 in a 3D nanoenvironment. PLoS ONE 2018, 13, e0191109. [CrossRef]

93. Du, X.H.; Li, W.M.; Du, G.S.; Cho, H.S.; Yu, M.; Fang, Q.; Lee, L.P.; Fang, J. Droplet Array-Based 3D Coculture System for High-Throughput Tumor Angiogenesis Assay. Anal. Chem. 2018, 90, 3253-3261. [CrossRef]

94. Da Cunha, C.B.; Klumpers, D.D.; Koshy, S.T.; Weaver, J.C.; Chaudhuri, O.; Seruca, R.; Carneiro, F.; Granja, P.L.; Mooney, D.J. CD44 alternative splicing in gastric cancer cells is regulated by culture dimensionality and matrix stiffness. Biomaterials 2016, 98, 152-162. [CrossRef] [PubMed]

95. Chiba, M.; Yokoyama, C.; Okada, M.; Hisatomi, H. Mitochondrial DNA reduced by hypoxic conditions in three-dimensional (3D) spheroid cell cultures. Tumor Biol. 2014, 35, 12689-12693. [CrossRef] [PubMed]

96. Beloueche-Babari, M.; Box, C.; Arunan, V.; Parkes, H.G.; Valenti, M.; Brandon, A.D.; Jackson, L.E.; Eccles, S.A.; Leach, M.O. Acquired resistance to EGFR tyrosine kinase inhibitors alters the metabolism of human head and neck squamous carcinoma cells and xenograft tumours. Br. J. Cancer 2015, 112, 1206-1214. [CrossRef] [PubMed]

97. Belisario, D.C.; Akman, M.; Godel, M.; Campani, V.; Patrizio, M.P.; Scotti, L.; Hattinger, C.M.; De Rosa, G.; Donadelli, M.; Serra, M.; et al. ABCA1/ABCB1 ratio determines chemo-and immune-sensitivity in human osteosarcoma. Cells 2020, 9, 647. [CrossRef] [PubMed]

98. Andersen, A.P.; Flinck, M.; Oernbo, E.K.; Pedersen, N.B.; Viuff, B.M.; Pedersen, S.F. Roles of acid-extruding ion transporters in regulation of breast cancer cell growth in a 3-dimensional microenvironment. Mol. Cancer 2016, 15, 45. [CrossRef] [PubMed]

99. Essid, N.; Chambard, J.C.; Elgaaied, A.B. Induction of epithelial-mesenchymal transition (EMT) and Gli1 expression in head and neck squamous cell carcinoma (HNSCC) spheroid cultures. Bosn. J. Basic Med Sci. 2018, 18, 336-346. [CrossRef]

100. Wang, K.; Kievit, F.M.; Erickson, A.E.; Silber, J.R.; Ellenbogen, R.G.; Zhang, M.Q. Culture on 3D Chitosan-Hyaluronic Acid Scaffolds Enhances Stem Cell Marker Expression and Drug Resistance in Human Glioblastoma Cancer Stem Cells. Adv. Healthc. Mater. 2016, 5, 3173-3181. [CrossRef] [PubMed]

101. Silva, I.; Estrada, M.F.; Pereira, C.V.; da Silva, A.B.; Bronze, M.R.; Alves, P.M.; Duarte, C.M.M.; Brito, C.; Serra, A.T. Polymethoxylated Flavones from Orange Peels Inhibit Cell Proliferation in a 3D Cell Model of Human Colorectal Cancer. Nutr. Cancer Int. J. 2018, 70, 257-266. [CrossRef] [PubMed]

102. Liu, L.J.; Zhang, J.; Xiao, Z.F.; Dai, B.; Sun, M.Y.; Chen, L.; Chen, B. Three-dimensional collagen scaffold enhances the human adenoid cystic carcinoma cancer stem cell and epithelial-mesenchymal transition properties. J. Biomed. Mater. Res. Part B Appl. Biomater. 2014, 102, 772-780. [CrossRef] [PubMed]

103. Chandrasekaran, S.; Marshall, J.R.; Messing, J.A.; Hsu, J.W.; King, M.R. TRAIL-Mediated Apoptosis in Breast Cancer Cells Cultured as 3D Spheroids. PLoS ONE 2014, 9, e0111487. [CrossRef] [PubMed]

104. Wang, G.B.; Zhao, T.T.; Song, X.P.; Zhong, W.; Yu, L.; Hua, W.X.; Xing, M.M.Q.; Qiu, X.Z. A 3-D multicellular tumor spheroid on ultrathin matrix coated single cancer cells provides a tumor microenvironment model to study epithelial-to-mesenchymal transitions. Polym. Chem. 2015, 6, 283-293. [CrossRef] 
105. Zeeberg, K.; Cardone, R.A.; Greco, M.R.; Saccomano, M.; Nohr-Nielsen, A.; Alves, F.; Pedersen, S.F.; Reshkin, S.J. Assessment of different 3D culture systems to study tumor phenotype and chemosensitivity in pancreatic ductal adenocarcinoma. Int. J. Oncol. 2016, 49, 243-252. [CrossRef] [PubMed]

106. Brodaczewska, K.K.; Bielecka, Z.F.; Maliszewska-Olejniczak, K.; Szczylik, C.; Porta, C.; Bartnik, E.; Czarnecka, A.M. Metastatic renal cell carcinoma cells growing in 3D on poly-D-lysine or laminin present a stem-like phenotype and drug resistance. Oncol. Rep. 2019, 42, 1878-1892. [CrossRef] [PubMed]

107. Ma, L.; Zhang, B.; Zhou, C.C.; Li, Y.T.; Li, B.J.; Yu, M.F.; Luo, Y.C.; Gao, L.; Zhang, D.; Xue, Q.; et al. The comparison genomics analysis with glioblastoma multiforme (GBM) cells under 3D and 2D cell culture conditions. Colloids Surf. B Biointerfaces 2018, 172, 665-673. [CrossRef] [PubMed]

108. Mc Cormick, B.P.; Belgorosky, D.; Langle, Y.; Balarino, N.; Sandes, E.; Eijan, A.M. Bacillus Calmette-Guerin improves local and systemic response to radiotherapy in invasive bladder cancer. Nitric Oxide Biol. Chem. 2017, 64, 22-30. [CrossRef] [PubMed]

109. Phan, N.L.; Pham, K.D.; Le Minh, P.; Nguyen, M.T.; Kim, N.P.; Truong, K.D.; Van Pham, P. Hopea odorata Extract Can Efficiently Kill Breast Cancer Cells and Cancer Stem-Like Cells in Three-Dimensional Culture More Than in Monolayer Cell Culture. Adv. Exp. Med. Biol. 2020, 20, 20.

110. Yoshii, Y.; Furukawa, T.; Waki, A.; Okuyama, H.; Inoue, M.; Itoh, M.; Zhang, M.R.; Wakizaka, H.; Sogawa, C.; Kiyono, Y.; et al. High-throughput screening with nanoimprinting 3D culture for efficient drug development by mimicking the tumor environment. Biomaterials 2015, 51, 278-289. [CrossRef]

111. Yang, J.N.; Zhao, S.J.; Ji, Y.F.; Zhao, L.L.; Kong, Q.Z.; Zhang, Q. Cell sheet-based multilayered liver tumor models for anti-cancer drug screening. Biotechnol. Lett. 2018, 40,427-435. [CrossRef] [PubMed]

112. Wang, Y.; Shi, W.; Kuss, M.; Mirza, S.; Qi, D.J.; Krasnoslobodtsev, A.; Zeng, J.P.; Band, H.; Band, V.; Duan, B. 3D Bioprinting of Breast Cancer Models for Drug Resistance Study. ACS Biomater. Sci. Eng. 2018, 4, 4401-4411. [CrossRef]

113. Popova, A.A.; Tronser, T.; Demir, K.; Haitz, P.; Kuodyte, K.; Starkuviene, V.; Wajda, P.; Levkin, P.A. Facile One Step Formation and Screening of Tumor Spheroids Using Droplet-Microarray Platform. Small 2019, 15. [CrossRef] [PubMed]

114. Nunes, A.S.; Costa, E.C.; Barros, A.S.; de Melo-Diogo, D.; Correia, I.J. Establishment of 2D Cell Cultures Derived From 3D MCF-7 Spheroids Displaying a Doxorubicin Resistant Profile. Biotechnol. J. 2019, 14, 1800268. [CrossRef] [PubMed]

115. Li, W.; Hu, X.; Wang, S.; Xing, Y.; Wang, H.; Nie, Y.; Liu, T.; Song, K. Multiple comparisons of three different sources of biomaterials in the application of tumor tissue engineering in vitro and in vivo. Int. J. Biol. Macromol. 2019, 130, 166-176. [CrossRef]

116. Lee, S.Y.; Jeong, E.K.; Jeon, H.M.; Kim, C.H.; Kang, H.S. Implication of necrosis-linked p53 aggregation in acquired apoptotic resistance to 5-FU in MCF-7 multicellular tumour spheroids. Oncol. Rep. 2010, 24, 73-79. [CrossRef] [PubMed]

117. Lee, K.J.; An, J.H.; Ha, C.W.; Son, Y.; Yang, D.Y.; Jung, J.; Lee, K.S.; Choi, J.W. 3D hierarchical, pyramid-based cancer cell chip for the detection of anticancer drug effects. J. Biomed. Nanotechnol. 2016, 12, 2125-2138. [CrossRef] [PubMed]

118. Lamberti, M.J.; Pansa, M.F.; Vera, R.E.; Vittar, N.B.R.; Rivarola, V.A. Photodynamic therapy potentiates the paracrine endothelial stimulation by colorectal cancer. Laser Phys. 2014, 24, 115602. [CrossRef]

119. Kim, B.J.; Hambley, T.W.; Bryce, N.S. Visualising the hypoxia selectivity of cobalt(III) prodrugs in tumour spheroids. J. Biol. Inorg. Chem. 2011, 16, S404.

120. Hossein, G.; Halvaei, S.; Heidarian, Y.; Dehghani-Ghobadi, Z.; Hassani, M.; Hosseini, H.; Naderi, N.; Sheikh Hassani, S. Pectasol-C Modified Citrus Pectin targets Galectin-3-induced STAT3 activation and synergize paclitaxel cytotoxic effect on ovarian cancer spheroids. Cancer Med. 2019, 8, 4315-4329. [CrossRef]

121. Hirt, C.; Papadimitropoulos, A.; Muraro, M.G.; Mele, V.; Panopoulos, E.; Cremonesi, E.; Ivanek, R.; Schultz-Thater, E.; Droeser, R.A.; Mengus, C.; et al. Bioreactor-engineered cancer tissue-like structures mimic phenotypes, gene expression profiles and drug resistance patterns observed "in vivo". Biomaterials 2015, 62, 138-146. [CrossRef] [PubMed]

122. Foglietta, F.; Spagnoli, G.C.; Muraro, M.G.; Ballestri, M.; Guerrini, A.; Ferroni, C.; Aluigi, A.; Sotgiu, G.; Varchi, G. Anticancer activity of paclitaxel-loaded keratin nanoparticles in two-dimensional and perfused three-dimensional breast cancer models. Int. J. Nanomed. 2018, 13, 4847-4867. [CrossRef]

123. Dmitriev, R.I.; Borisov, S.M.; Jenkins, J.; Papkovsky, D.B. Multi-parametric imaging of tumor spheroids with ultra-bright and tunable nanoparticle O-2 probes. In Imaging, Manipulation, and Analysis of Biomolecules, Cells, and Tissues Xiii; Farkas, D.L., Nicolau, D.V., Nicolau, R.C., Eds.; SPIE: Bellingham, WA, USA, 2015; Volume 9328.

124. Lee, H.R.; Leslie, F.; Azarin, S.M. A facile in vitro platform to study cancer cell dormancy under hypoxic microenvironments using CoCl2. J. Biol. Eng. 2018, 12, 12. [CrossRef]

125. Pezzuto, A.; Carico, E. Role of HIF-1 in Cancer Progression: Novel Insights. A Review. Curr. Mol. Med. 2018, 18, 343-351. [CrossRef] [PubMed]

126. Semenza, G.L.; Wang, G.L. A nuclear factor induced by hypoxia via de novo protein synthesis binds to the human erythropoietin gene enhancer at a site required for transcriptional activation. Mol. Cell. Biol. 1992, 12, 5447-5454. [CrossRef] [PubMed]

127. Saxena, K.; Jolly, M.K. Acute vs. Chronic vs. Cyclic Hypoxia: Their Differential Dynamics, Molecular Mechanisms, and Effects on Tumor Progression. Biomolecules 2019, 9, 339. [CrossRef]

128. Xiong, G.-F.; Xu, R. Function of cancer cell-derived extracellular matrix in tumor progression. J. Cancer Metastasis Treat. 2016, 2, 357-364. [CrossRef]

129. Eble, J.A.; Niland, S. The extracellular matrix in tumor progression and metastasis. Clin. Exp. Metastasis 2019, 36, 171-198. [CrossRef] 
130. Dawood, S.; Austin, L.; Cristofanilli, M. Cancer stem cells: Implications for cancer therapy. Oncology 2014, $28,1101-1107$. [PubMed]

131. Denny, W.A.; Wilson, W.R. Tirapazamine: A bioreductive anticancer drug that exploits tumour hypoxia. Expert Opin. Investig. Drugs 2000, 9, 2889-2901. [CrossRef]

132. Imamura, Y.; Mukohara, T.; Shimono, Y.; Funakoshi, Y.; Chayahara, N.; Toyoda, M.; Kiyota, N.; Takao, S.; Kono, S.; Nakatsura, T.; et al. Comparison of 2D- and 3D-culture models as drug-testing platforms in breast cancer. Oncol. Rep. 2015, 33, 1837-1843. [CrossRef] [PubMed]

133. Ward Rashidi, M.R.; Mehta, P.; Bregenzer, M.; Raghavan, S.; Fleck, E.M.; Horst, E.N.; Harissa, Z.; Ravikumar, V.; Brady, S.; Bild, A.; et al. Engineered 3D Model of Cancer Stem Cell Enrichment and Chemoresistance. Neoplasia 2019, 21, 822-836. [CrossRef] [PubMed]

134. Mak, M.; Spill, F.; Kamm, R.D.; Zaman, M.H. Single-Cell Migration in Complex Microenvironments: Mechanics and Signaling Dynamics. J. Biomech. Eng. 2016, 138, 021004. [CrossRef] [PubMed]

135. Nature Research. Cell Invasion. 2021. Available online: https://www.nature.com/subjects/cell-invasion\#: \{\}:text=Definition, secondary\%20sites \%20and\%20form\%20metastases. (accessed on 18 January 2021).

136. He, X.; Lee, B.; Jiang, Y. Cell-ECM Interactions in Tumor Invasion. Adv. Exp. Med. Biol. 2016, 936, 73-91. [CrossRef] [PubMed]

\section{Short Biography of Authors}

Ye Liu is currently completing an MSc in Surgical and Interventional Sciences at UCL, whilst working as a clinician in oral and maxillofacial surgery at Addenbrooke's hospital Cambridge.

Zahra Mohri has worked as a postdoctoral research fellow at the Institute of Cancer Research and Imperial College. Following two years of Teaching Fellow role at UCL, Zahra is currently teaching at Imperial.

Wissal Alshiekh is also a clinician with an interest in surgery, currently undertaking an MSc in Burns, Plastics and Reconstructive Surgery at UCL.

Umber Cheema holds a chair in Bioengineering at UCL. She is also the Head of the Centre for 3D models of Health and Disease. Her research focuses on developing biomimetic models of tissues to interrogate mechanisms of disease propagation. 